\title{
Mondor's disease of the breast: a case series
}

\author{
K. Ben Hamida ${ }^{1,2^{*}}$, M. Ghalleb ${ }^{1,2}$, A. Triki ${ }^{1,2}$, I. Jebir ${ }^{1,2}$, R. Makhlouf ${ }^{1,2}$ and H. Touinsi ${ }^{1,2}$
}

\begin{abstract}
Background: Mondor's disease of the breast (MDB) is a rare and benign disorder of the breast. It is characterized by thrombophlebitis of the superficial veins of the chest wall. Clinically, it manifests as a cord-like induration of the breast area. MDB resolves spontaneously without sequela.

Case presentation: We report cases of three Caucasian African patients aged 29, 40 and 34, respectively. One patient was under progestative contraception. All the patients had a cord-like induration on the chest wall. Ultrasonography was performed in all patients and was normal in two cases and showed a thrombotic vein in one case. All the patients had symptomatic treatment with total resolution of symptoms within 1 to 4 weeks. No relapse was observed.

Conclusion: MDB is benign in most cases. However, it is not to be taken lightly, because it can be the manifestation of an underlying disease such as breast cancer. The diagnosis is based on clinical findings; ultrasonography can be helpful for the diagnosis. Treatment is based on analgesic and anti-inflammatory drugs.
\end{abstract}

Keywords: Mondor's disease, Breast disease, Superficial thrombophlebitis

\section{Background}

Mondor's disease of the breast (MDB) is a rare and benign condition. It is characterized by thrombophlebitis of the subcutaneous venous network of the anterior chest wall. It was well described by the French surgeon Henri Mondor, who in 1939 published a case series where he described the disorder in detail [1]. In $50-60 \%$ of cases, no cause is found (primary disease), while in $40-50 \%$ of cases, some enhancing factors may be present [2].

The rarity of the disease and the absence of clear diagnostic criteria cause it to be underdiagnosed. In some cases, the presence of MDB led to the diagnosis of an underlying breast cancer. Thus, it raises the question of a possible association between breast cancer and MDB.

We aim through this study to report our experience about MDB and to review the existing literature.
*Correspondence: karim.ben.hamida.92@gmail.com

${ }^{1}$ Surgery Department, Mohamed Taher El Maamouri Hospital, Nabeul, Tunisia

Full list of author information is available at the end of the article

\section{Case presentation}

\section{Case 1}

A 29-year-old Caucasian African women, with no particular past medical history, presented with 24-hour right breast pain. The patient's history revealed a local trauma 7 days before presentation. The physical exam revealed a 5-cm painless cord-like subcutaneous induration in the periareolar region of the right breast, arising in the circulus venosus of Haller (Fig. 1). No other signs were found.

A Doppler ultrasound was performed and was normal. The patient underwent 7 days of nonsteroidal antiinflammatory treatment. The pain resolved within 1 week and the induration within 3 weeks. No relapse was reported after 6 months of follow-up. Screening mammogram as prescribed in the national program was performed 1 month after resolution of the symptoms and was normal.

\section{Case 2}

A 40-year-old Caucasian African women with no particular past medical history presented with a 7-day subcutaneous cord-like lesion in the left breast. The physical exam revealed a $6-\mathrm{cm}$ cord-like lesion in the original author(s) and the source, provide a link to the Creative Commons licence, and indicate if changes were made. The images or other third party material in this article are included in the article's Creative Commons licence, unless indicated otherwise in a credit line to the material. If material is not included in the article's Creative Commons licence and your intended use is not permitted by statutory regulation or exceeds the permitted use, you will need to obtain permission directly from the copyright holder. To view a copy of this licence, visit http://creativecommons.org/licenses/by/4.0/. The Creative Commons Public Domain Dedication waiver (http://creativeco mmons.org/publicdomain/zero/1.0/) applies to the data made available in this article, unless otherwise stated in a credit line to the data. 


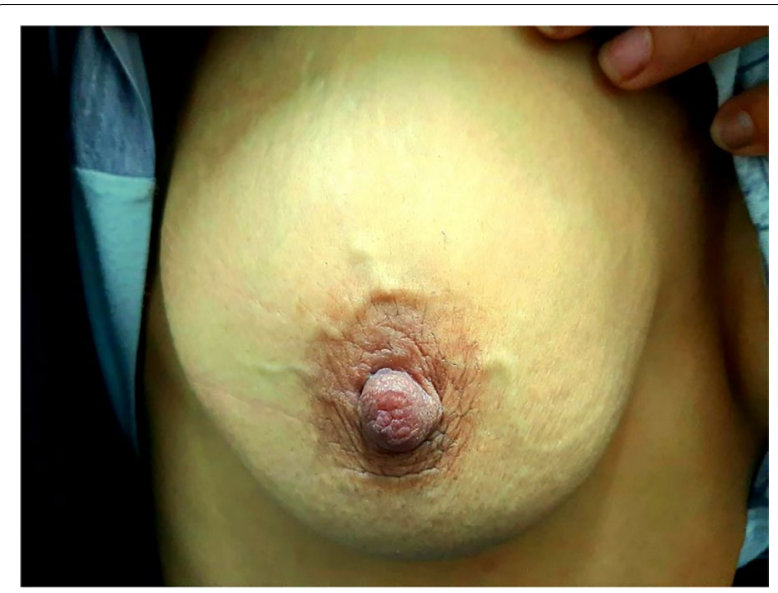

Fig. 1 Cord-like lesion of the circulus venosus of Haller of the right breast

outer upper quadrant of the left breast (Fig. 2). There was erythema around the lesion, and the palpation was painless.

Ultrasonography showed an incompressible subcutaneous vein. The patient underwent nonsteroidal anti-inflammatory treatment, and the clinical findings disappeared after 1 month. Screening mammogram as prescribed in the national program was performed 1 month after the resolution of the symptoms and was normal.

\section{Case 3}

A 34-year-old Caucasian African women presented with an aching right breast. She had no past medical history

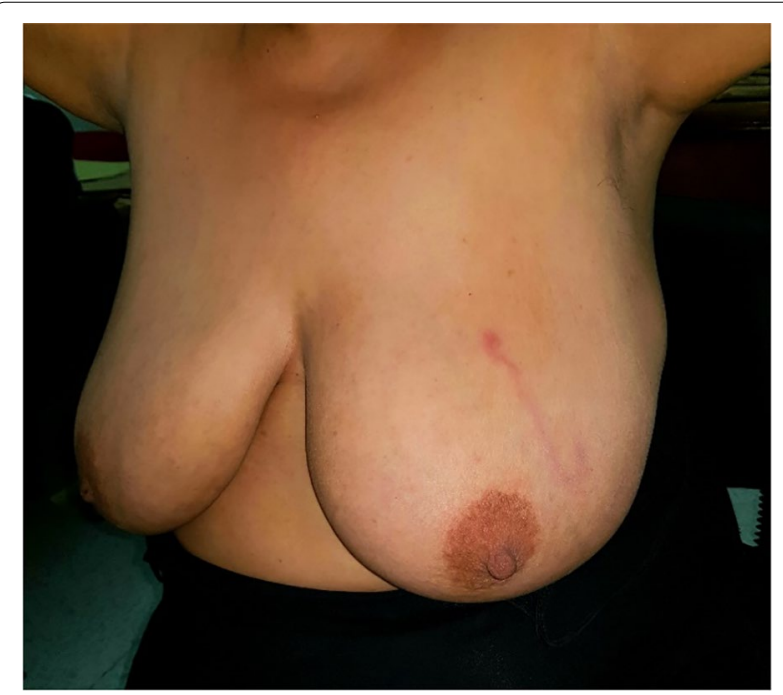

Fig. 2 Cord-like induration of outer upper quadrant of the left breast of breast injury or breast disease. She had been on oral estro-progestative contraception for 11 years. A $7-\mathrm{cm}$ indurated and painful cord-like structure was present in the outer upper quadrant of the right breast on physical examination. The cords radiated from the retro-areolar region towards the axillary fossa. The tract adhered to the skin, with mild cutaneous retraction without erythema. On sonography, there was an intraluminal thrombus in a tubular structure (Fig. 3). No flow was present in the structure on color or spectral Doppler studies.

The patient received painkillers and a nonsteroidal anti-inflammatory drug. Complete recovery within 10 days marked the evolution of the disease. Screening mammogram as prescribed in the national program was performed 1 month after the resolution of the symptoms and was normal.

\section{Discussion}

The incidence of MDB is unknown due to its rarity and the lack of awareness of clinical findings, especially in the primary care setting. Quéhé et al. found only 400 cases reported in the literature [3]. The reported sex ratio is 3:1 $[4,5]$. However, it seems that female patients are more involved than male patients [2]. The average age is from 30 to 60 years, with extremes ranging from 19 to 70 years [3].

MDB is idiopathic in $50-60 \%$ of cases. In $40-50 \%$ of cases, a favoring factor can be present [2]. Many case reports suggest the presence of a relation between local trauma (such as vigorous exercise, tight brassiere, or direct injury) and the onset of the palpable cord [6].

In a retrospective study of 652 female patients who underwent aesthetic breast surgery, Goldman and Wollina [7] found three MDB cases. Catania et al. found eight MDB cases associated with breast cancer among a total of $68 \mathrm{MD}$ cases [8].

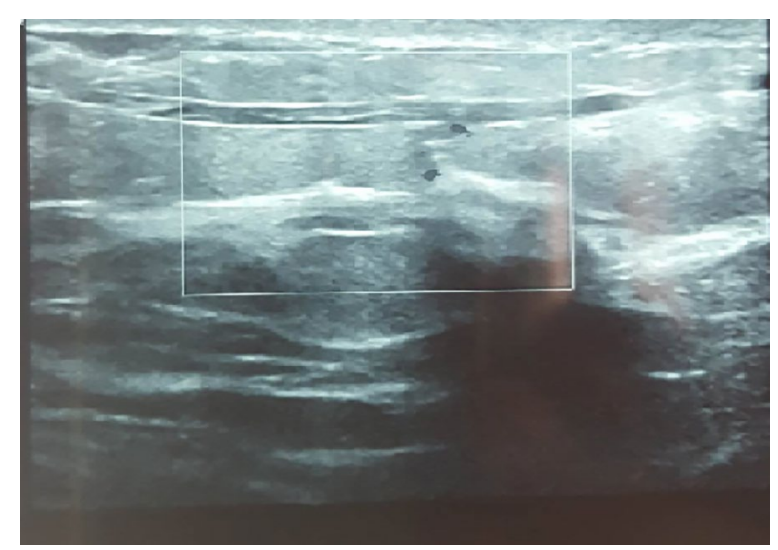

Fig. 3 Intraluminal thrombus on sonography 
There are few references concerning MDB during pregnancy $[9,10]$. The clinical presentation is not specific, and it is unlikely that the physiological hypercoagulability is responsible for the generation of MDB. Penile lesion may be related to neoplasms, excessive sexual activity, trauma, or abstinence [11]. MD of the axilla, known as axillary web syndrome, has been documented following axillary surgery [12].

The only clinical sign of MDB is an acute, usually painful, cord-like induration arising in the chest wall area, which is the patient's main complaint. The diagnosis is based on medical history and physical examination. Further examination is usually not necessary.

Depending on the problematic vein, the induration topography may change. The lesion most commonly involves the thoracoepigastric vein and more rarely the lateral thoracic vein or superior epigastric vein [3]. Ultrasound may be needed when the clinical presentation is not suggestive. It shows incompressible tubular structures with anechoic or hypoechoic content [13]. Color Doppler can also be applied in the absence of a flow signal inside the vein [14].

Mammography is performed to determine the etiology rather than to confirm the diagnosis. In fact, since the association between MDB and breast cancer has been estimated at around 4\% (1.8\% in Herman's series and $12.7 \%$ in Catania's), mammography should be considered in both genders. MDB associated with breast cancer in male patients has been reported $[8,15]$. Magnetic resonance imaging and other imaging techniques are not recommended for evaluating MDB [16] and may cause unnecessary health expenses.

In general, MDB is a spontaneously regressive disease within 4 to 8 weeks, and no particular treatment is needed [17]. Warm compresses, painkillers and nonsteroidal anti-inflammatory drugs and abstinence from irritating clothing or activities constitute first-line treatment [18]. Most lesions will resolve with no other further treatment needed. However, in some cases, the cord-like induration may be palpable for several months [9].

Some authors have reported efficiency of anticoagulation treatment in the acute stage of the disease [19], such as low-molecular-weight heparin or aspirin. Local application of anticoagulation has been described in some cases of penile Mondor's disease [20]. Local injection of triamcinolone has been successfully tested in shortening the disease in Mondor's cord after breast augmentation [21]. Surgery can be considered in the case of unbearable pain [22].

MDB is a self-limited condition that resolves spontaneously with no sequela. However, patients should be educated on the importance of follow-up.

\section{Conclusion}

MD is a rare clinical condition for which the etiopathogenesis has yet to be elucidated. It affects more women than men. Symptoms can occur in sensitive areas, and it can become a source of discomfort for either female or male patients. Greater awareness of patients' complaints and clinical findings is required, since it is a rare disease. Usually, no further investigation is needed. Mammography is considered in women with MDB when a risk of an underlying disease is identified. Symptoms usually resolve spontaneously.

\section{Acknowledgements \\ The paramedical team of the surgery department of the Mohamed Taher El Maamouri Hospital, Nabeul.}

\section{Authors' contributions}

$\mathrm{KBH}, \mathrm{MG}$ : Data collection, review of the literature, draft of the manuscript. AT, IJ, RM, HT: Review of the literature, draft of the manuscript. All authors read and approved the final manuscript.

\section{Funding}

No source of funding.

\section{Availability of data and materials}

All data were taken from the patient's medical folder available at the archive of our institution.

\section{Ethics approval and consent to participate}

The authors declare no conflicts of interest, and declare that this work was conducted with all due respect to the code of ethics under the supervision of the medical and ethics committee of Mohamed Taher Maamouri Hospital of Nabeul, Tunisia.

\section{Consent for publication}

Written informed consent was obtained from the patients for publication of this case report and any accompanying images. A copy of the written consent is available for review by the Editor-in-Chief of this journal.

\section{Competing interests}

The authors declare that they have no competing interests.

\section{Author details}

${ }^{1}$ Surgery Department, Mohamed Taher El Maamouri Hospital, Nabeul, Tunisia.

${ }^{2}$ Faculty of Medicine of Tunis, Tunis, Tunisia.

Received: 1 January 2021 Accepted: 28 January 2021

Published online: 02 April 2021

\section{References}

1. Mondor $\mathrm{H}$. Tronculite sous-cutanee subaigue de la paroi thoraccique antero-laterale. Mem Acad Chir. 2020;65:1271-8.

2. Pugh CM, DeWitty RL. Mondor's disease. J Natl Med Assoc. 1996;88(6):359-63.

3. Quéhé P, Saliou A-H, Guias B, Bressollette L. Maladie de Mondor. À propos de trois cas et revue de la littérature. J Mal Vasc. 2009;34(1):54-60.

4. Weinstein EC. Mondor's disease. West J Med. 1975;123(1):56-7.

5. Herrmann JB. Thrombophlebitis of breast and contiguous thoracicoabdominal wall (Mondor's disease). N Y State J Med. 1966;66(24):3146-52.

6. Tröbinger C, Wiedermann CJ. Bodybuilding-induced Mondor's disease of the chest wall. Phys Ther Sport. 2017;23:133-5. https://doi.org/10.1016/j. ptsp.2016.09.002.

7. Goldman A, Wollina U. Mondor's disease after aesthetic breast surgery: a case series and literature review. J Cutan Aesthetic Surg. 2018;11(3):132-5. 
8. Catania S, Zurrida S. Mondor's disease and breast cancer. Cancer. 1992;4:2267-70

9. Hacker SM. Axillary string phlebitis in pregnancy: a variant of Mondor's disease. J Am Acad Dermatol. 1994;30(4):636-8. https://doi.org/10.1016/ s0190-9622(94)70074-5.

10. Duff P. Mondor disease in pregnancy. Obstet Gynecol. 1981;58(1):117-9.

11. Nazir SS, Khan M. Thrombosis of the dorsal vein of the penis (Mondor's disease): a case report and review of the literature. Indian J Urol. 2010;26(3):431-3.

12. Koehler LA, Haddad TC, Hunter DW, Tuttle TM. Axillary web syndrome following breast cancer surgery: symptoms, complications, and management strategies. Breast Cancer Dove Med. 2018;11:13-9.

13. Yanik B, Conkbayir I, Oner O, Hekimoğlu B. Imaging findings in Mondor's disease. J Clin Ultrasound. 2003;31(2):103-7. https://doi.org/10.1002/jcu. 10134.

14. Kim HS, Cha ES, Kim HH, Yoo JY. Spectrum of sonographic findings in superficial breast masses. J Ultrasound Med. 2005;24(5):663-80. https:// doi.org/10.7863/jum.2005.24.5.663.

15. de Godoy JM, Godoy MF, Batigália F, Braile DM. The association of Mondor's disease with protein S deficiency: case report and review of literature. J Thromb Thrombol. 2002;13(3):187-9. https://doi.org/10.1023/a: 1020487225611.

16 Adeniji-Sofoluwe A, Afolabi O. Mondor's disease: classical imaging findings in the breast. BMJ Case Rep. 2011;2011:bcr0720114521.
17. Markopoulos C, Kouskos E, Mantas D, Kakisis J, Antonopoulou Z, Kontzoglou K, et al. Mondor's disease of the breast: is there any relation to breast cancer? Eur J Gynaecol Oncol. 2005;26(2):213-4.

18. Walsh JC, Poimboeuf S, Garvin DS. A common presentation to an uncommon disease. Penile Mondor's disease: a case report and literature review. Int Med Case Rep J. 2014;7:155-7.

19. Belleflamme M, Penaloza A, Thoma M, Hainaut P, Thys F. Mondor disease: a case report in ED. Am J Emerg Med. 2012;30(7):1325.e1-3

20. Al-Mwalad M, Loertzer $\mathrm{H}$, Wicht $\mathrm{A}$, et al. Subcutaneous penile vein thrombosis (Penile Mondor's disease): pathogenesis, diagnosis, and therapy. Urology. 2006;67:586-8.

21. Menta A, Fouad TM, Lucci A, Le-Petross H, Stauder MC, Woodward WA, Ueno NT, Lim B. Inflammatory breast cancer: what to know about this unique, aggressive breast cancer. Surg Clin N Am. 2018;98(4):787-800.

22. Shetty MK, Watson AB. Mondor's disease of the breast: sonographic and mammographic findings. AJR Am J Roentgenol. 2001;177(4):893-6. https://doi.org/10.2214/ajr.177.4.1770893.

\section{Publisher's Note}

Springer Nature remains neutral with regard to jurisdictional claims in published maps and institutional affiliations.
Ready to submit your research? Choose BMC and benefit from:

- fast, convenient online submission

- thorough peer review by experienced researchers in your field

- rapid publication on acceptance

- support for research data, including large and complex data types

- gold Open Access which fosters wider collaboration and increased citations

- maximum visibility for your research: over 100M website views per year

At BMC, research is always in progress.

Learn more biomedcentral.com/submissions 